\title{
An Unusual Hexose-ATP-Kinase with Two Catalytic Sites and a Role in Carbon Catabolite Repression in the Yeast Schwanniomyces occidentalis
}

\author{
By A. KATE MCCANN, F. HILBERG, $\dagger$ P. KENWORTHY AND \\ J. A. BARNETT* \\ ${ }^{1}$ School of Biological Sciences, University of East Anglia, Norwich NR4 7TJ, UK
}

(Received 26 June 1986; revised 26 August 1986)

\begin{abstract}
The hexose-ATP-kinase of wild-type Schwanniomyces occidentalis (CBS 819) is, like hexokinase PII of Saccharomyces cerevisiae, associated with carbon catabolite repression and phosphorylates D-glucose and D-fructose. The kinase of Schw. occidentalis repression-resistant (Dog $\left.{ }^{\mathrm{R}}\right)$ mutants phosphorylates D-glucose, but not D-fructose. Subjecting the wild-type enzyme to $45^{\circ} \mathrm{C}$ for a few minutes appears to alter its activity, specificity and kinetic characteristics to that of the mutant enzyme. Fast protein liquid chromatography, with anion-exchange or gel-filtration columns, gel-electrophoresis, and DNA hybridization with the hex $I^{\mathrm{r}}$ mutant of the $H X K 2$ (hexokinase PII) gene of Sacch. cerevisiae, all failed to resolve more than one hexose-ATP-kinase in Schw. occidentalis. Hence $S c h w$. occidentalis appears to have a single hexose-ATP-kinase, $M_{\mathrm{r}}$ $\sim 72000$, with two catalytic sites, analogous to the aspartate kinase/homoserine dehydrogenase of Escherichia coli. One site is hexokinase-like and associated with catabolite repression and the other is glucokinase-like. Values for apparent $K_{\mathrm{m}}$ were $7.2 \mathrm{mM}$-D-fructose and $0.55 \mathrm{mM}$-D-glucose ('hexokinase' site) and 0.078 mM-D-glucose ('glucokinase' site).
\end{abstract}

\section{INTRODUCTION}

In an industrial fermentation, D-glucose, liberated in, say, starch or sucrose hydrolysis, can slow down the whole process. This is because the repression of enzyme synthesis by glucose (carbon catabolite repression) is a major general regulatory system in yeasts (Mahler et al., 1981). Many yeast enzymes are subject to glucose repression, such as those of (i) gluconeogenesis (Gancedo et al., 1965; Gancedo \& Schwerzmann, 1976; Haarasilta \& Oura, 1975; Witt et al., 1966), (ii) the tricarboxylic acid cycle (Polakis \& Bartley, 1965), (iii) the glyoxylate cycle (Barnett \& Kornberg, 1960), in addition to (iv) carriers and enzymes responsible for the transport and initial metabolism of exogenously supplied sugars and their derivatives (Barnett, 1976, 1981), and (v) amylases (McCann \& Barnett, 1986).

Saccharomyces cerevisiae possesses at least three hexose-ATP-kinases, namely $(a)$ two hexokinases (EC 2.7.1.1), PI and PII (Colowick, 1973), which phosphorylate both D-glucose and D-fructose and $(b)$ the D-glucose-specific glucokinase (EC 2.7.1.12) (Maitra, 1970; Gancedo et al., 1977; Maitra \& Lobo, 1983). In addition to its catalytic role, hexokinase PII triggers glucose repression (Entian, 1980; Entian \& Mecke, 1982). Repression-resistant mutants, selected in the presence of 2-deoxy-D-glucose (Dog ${ }^{\mathrm{R}}$ mutants; see Zimmermann \& Scheel, 1977), are deficient in PII. However, the relations between the hexose phosphorylating enzymes and their role in catabolite repression vary with different yeasts. For example, Dog ${ }^{\mathrm{R}}$

$\dagger$ Present address: Heinrich-Pette-Institut für Experimentelle Virologie und Immunologie an der Universität Hamburg, Martinstrasse 52, D-2000 Hamburg 20, FRG.

Abbreviations: DogR , 2-deoxy-D-glucose resistant; FPLC, fast protein liquid chromatography; G/F ratio, ratio of rate of phosphorylation of D-glucose to that of D-fructose; PMSF, phenylmethylsulphonyl fluoride; TEA, triethanolamine. 
mutants of Rhodotorula glutinis may lose activity of glucokinase, not hexokinase (Mahlberg et al., 1985). Furthermore, from the work of McCann \& Barnett (1984), Schwanniomyces occidentalis appears to have only a single hexokinase, which is lost in $\operatorname{Dog}^{\mathrm{R}}$ mutants. The present paper reports some unusual characteristics of this enzyme.

\section{METHODS}

Organisms, growth and preparation of suspensions. Yeast stock cultures were maintained at $3{ }^{\circ} \mathrm{C}$ on slopes of Difco Bacto YM agar and all incubations were at $25 \pm 0.5^{\circ} \mathrm{C}$. For enzymic studies, each culture (1 litre) of Schwanniomyces occidentalis Klöcker CBS 819 and its Dog ${ }^{\mathrm{R}}$ mutant 819-11 (McCann \& Barnett, 1984) was grown in a rotating (100-110 r.p.m.) 10 litre flask (Mitchell, 1949). The growth medium was Difco Bacto Yeast Nitrogen Base (without amino acids) (YNB) with $20 \mathrm{mM}$-D-glucose or D-xylose. A strain of Saccharomyces cerevisiae Meyen ex Hansen (cat1.33-14A, obtained from K.-D. Entian) was grown similarly, but in YNB with $0.5 \%$ (w/w) Difco Bacto Yeast Extract and $25 \mathrm{~mm}$-ethanol (as carbon source). When grown to about $0.4 \mathrm{mg}$ dry weight $\mathrm{ml}^{-1}$ (estimated from the optical density at $640 \mathrm{~nm}$ ), the yeast was harvested by centrifugation for $10 \mathrm{~min}$ at about $5000 \mathrm{~g}$ and $4{ }^{\circ} \mathrm{C}$ and washed in ice-cold $50 \mathrm{~mm}$-triethanolamine buffer (pH 7.6) (TEA), and the pellet was stored at $-20^{\circ} \mathrm{C}$.

Enzyme preparations. Crude extracts were prepared (Ciriacy, 1976) by whirlimixing for $90 \mathrm{~s}$ about $70 \mathrm{mg}$ dry wt of thawed yeast with $2.5 \mathrm{~g}$ fine glass beads (no. 9 , Jencons) in $0.5 \mathrm{ml} \mathrm{TEA}$, both ice-cold, in a plastic test tube $(95 \times$ $16 \mathrm{~mm}$ ). A further $1.0 \mathrm{ml}$ TEA, ice-cold, was mixed with the broken yeast and the suspension centrifuged at about $20000 \mathrm{~g}$ for $30 \mathrm{~min}$ at about $4{ }^{\circ} \mathrm{C}$. The supernatant fluid was desalted through a Sephadex G25 column, giving a final protein concentration of between 200 and $500 \mu \mathrm{g} \mathrm{ml}^{-1}$, and either purified or used directly for enzyme assays. Buffers contained 2 mM-phenylmethylsulphonyl fluoride (PMSF) (Fahrney \& Gold, 1963; Schulze et al., 1966) and 2 mM-DTT.

The hexose-ATP-kinase was purified from samples of extract (up to $4 \mathrm{ml}$ ) by fast protein liquid chromatography (FPLC; Pharmacia), using either an anion-exchange or a gel-filtration column, each at room temperature. The anion-exchange column, (Mono Q HR 5/5) was used with buffer A, $20 \mathrm{mM}$-piperazine (pH 6.0) or $20 \mathrm{mM}$-TEA

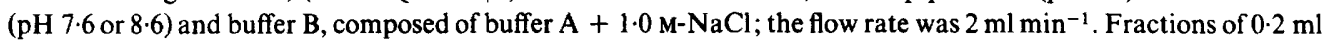
were collected. Elution involved $4 \mathrm{ml}$ buffer $A$ and then a gradient of $20 \mathrm{ml}$ buffer $\mathrm{B}$, to give, finally, $0.35 \mathrm{M}-\mathrm{NaCl}$. The gel filtration (Superose 12) column was used with 20 mM-TEA buffer (pH 7.6) and a flow rate of $0.5 \mathrm{ml} \mathrm{min}^{-1}$. Fractions of $0.25 \mathrm{ml}$ were collected. For some experiments, including the electrophoretograms, the purified samples were concentrated five- or tenfold by centrifugal ultrafiltration with Centricon Microconcentrators (Amicon).

Electrophoresis. Crude or purified extracts were electrophoresed on $94 \times 76 \mathrm{~mm}$ celiulose acetate plates (Titan III, Helena Laboratories, Beaumont, Tx., USA) at $4{ }^{\circ} \mathrm{C}$, using $10 \mathrm{~mm}$-Tris/glycine buffer (pH 8.5 ) or $0.1 \mathrm{M}-$ Tris/citrate ( $\mathrm{pH} \mathrm{7.6)}$, as a continuous buffer system, for about $20 \mathrm{~min}$ at $200 \mathrm{~V}$. These plates were designed for medical applications, but have been used effectively for separating dehydrogenases (e.g. Searle, 1985). HexoseATP-kinase activity was detected on the plates by overlaying, at about $20^{\circ} \mathrm{C}$ for $15 \mathrm{~min}$, with a solution of $100 \mathrm{mM}$ TEA ( $\mathrm{pH} 7.6$ ), gelled with $1.5 \%$ (w/v) agarose, containing $1.5 \mathrm{~mm}-\mathrm{NADP}, 2 \mathrm{~mm}-\mathrm{ATP}, 1 \mathrm{mM}-\mathrm{D}-\mathrm{glucose}, 0.3 \mathrm{~mm}-$ phenazine methosulphate, $0.7 \mathrm{mM}$-(3-[4,5-dimethylthiazol-2-yl]-2,5-diphenyl monotetrazolium bromide) (MTT), glucose-6-phosphate dehydrogenase (EC 1.1.1.49) $\left(18\right.$ units $\left.\mathrm{ml}^{-1}\right)$ and, when detecting phosphorylation of $\mathrm{D}$ fructose, glucose-6-phosphate isomerase (EC 5.3.1.9) $\left(20\right.$ units $\left.\mathrm{ml}^{-1}\right)$.

Measurements of hexose phosphorylation. Phosphorylation of D-glucose or D-fructose, by crude or partly purified extracts, was estimated from the rate of the coupled NADP-linked oxidation of D-glucose 6-phosphate (Fromm \& Zewe, 1962; Maitra, 1975), with increase in NADPH concentration measured at $340 \mathrm{~nm}$. Reaction mixtures consisted of $1.0 \mathrm{mM}$-D-glucose or $20 \mathrm{mM}$-D-fructose, $1.0 \mathrm{mM}-\mathrm{NADP}, 1.0 \mathrm{mM}$-ATP and 10 units glucose-6phosphate dehydrogenase $\mathrm{ml}^{-1}$, with 5 units glucose-6-phosphate isomerase $\mathrm{ml}^{-1}$ added for estimating $\mathrm{D}$-fructose phosphorylation. In certain experiments, analogues replaced ATP, namely, CTP, ITP, GTP or UTP, each at $1.0 \mathrm{~mm}$. Apparent $K_{\mathrm{m}}$ was estimated at least in triplicate, in each case, using the program Statstream (Bangham, 1985), running on an Apple II microcomputer. Values were chosen, by iteration, that best fitted the MichaelisMenten equation to the experimental measurements (Colquhoun, 1971).

Plasmid. The structural gene for hexokinase PII is $H X K 2$ and its mutant allele is $h x k 2$ (Lobo \& Maitra, 1977c), formerly called $H E X I$ and hexl, respectively. The mutant alleles, affecting the regulatory but not the catalytic function of hexokinase PII, are designated hex $I^{\mathrm{r}}$ (see Entian et al., 1985). The YRp/hex $l^{\mathrm{r}}$-1804 plasmid was kindly supplied by K.-D. Entian.

Preparation of hybridization probe. The hex Ir DNA fragment was purified from the YRp/hex/r-1804 plasmid. Caesium chloride-purified YRp/hexI $I^{\mathrm{r}} 1804$ was digested with HindIII and Pstl (see Maniatis et al., 1982) combined and run on a preparative agarose gel. The $0.87 \mathrm{kbp}$ fragment, which contained most of the hex $l^{\mathrm{r}}$ gene (Entian et al., 1985), was recovered from the gel by the method of Dretzen et al. (1981) and used as the probe in hybridization experiments. 


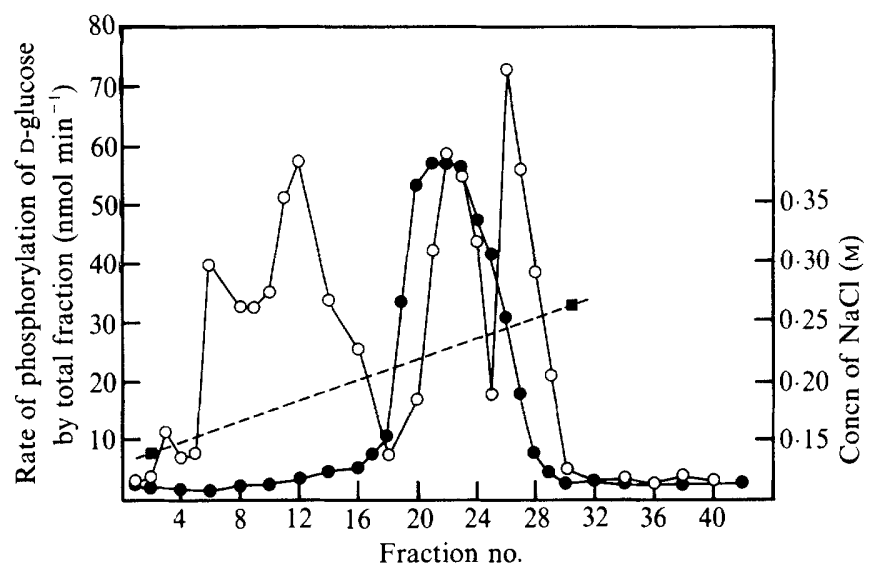

Fig. 1. Partial purification of hexose-ATP-kinase of Schw. occidentalis (CBS 819, wild-type) and Sacch. cerevisiae (cat 1.33-14 A) by ion-exchange chromatography. For each yeast, crude extracts were applied to an anion-exchange (Mono Q) column, which was eluted with a concentration gradient of $\mathrm{NaCl}$ in 20 mm-piperazine buffer ( $\mathrm{pH} \mathrm{6.0)}$ ). Phosphorylation of D-glucose was measured at $25^{\circ} \mathrm{C}$, as described in Methods. No activity was detected in fractions obtained with $<0 \cdot 13 \mathrm{M}-\mathrm{NaCl}$. $\mathrm{O}-\mathrm{O}$, cat1.33-14 A; $---\mathbf{0}, \mathrm{NaCl}$.

Radioactive labelling of DNA. DNA fragments were labelled with $\left[{ }^{32} \mathrm{P}\right] \mathrm{dCTP}$ by nick translation (Kelly et al., 1970).

Hybridization. After restriction digestion with (i) EcoRI and (ii) HindIII (see Maniatis et al., 1982) and agarose gel electrophoresis, DNA fragments were adsorbed on to nitrocellulose filters and heated overnight at $65^{\circ} \mathrm{C}$. For hybridization with labelled DNA (Southern, 1975), the temperature was kept at $65^{\circ} \mathrm{C}$ for $16 \mathrm{~h}$. The hybridization filters were exposed to Fuji RX film $(20 \times 40 \mathrm{~cm})$. In order to strengthen the radioactive signals, intensifying screens were used at $-70^{\circ} \mathrm{C}$.

\section{RESULTS AND DISCUSSION}

Crude extracts of wild-type Schw. occidentalis CBS 819 phosphorylated both D-glucose and Dfructose, whilst corresponding rates of phosphorylation by extracts of the Dog ${ }^{\mathrm{R}}$ mutant, 819-11, were only $20 \%$ that of the wild-type for D-glucose and $2 \%$ for D-fructose (McCann \& Barnett, 1984). A naive interpretation of these results, in terms of the findings for Sacch. cerevisiae (Lobo \& Maitra, 1977b; Entian, 1980), was that the wild-type possessed a glucokinase and a single hexokinase and that the latter was lost in the mutant. So, in order to test this interpretation, the wild-type was examined to establish the number and character of its hexose-ATP-kinases.

\section{FPLC analysis}

Attempts were made to separate the enzymes responsible for hexose-ATP-kinase activities by FPLC anion-exchange chromatography and by gel filtration. As a control, extracts of Sacch. cerevisiae were also chromatographed, as this yeast has already been shown to give three peaks of hexose-ATP-kinase activity (e.g. Barnard, 1975; Entian \& Mecke, 1982; Fernandez et al., 1985; Kopetzki \& Entian, 1985). Although Sacch. cerevisiae did, indeed, give at least three peaks (Fig. 1), the elution of hexose-ATP-kinase from wild-type Schw. occidentalis CBS 819, with D-glucose as substrate, gave only a single activity peak, which also corresponded to the phosphorylative activity against D-fructose. Similarly, only a single peak was obtained with gel filtration. With $S c h w$. occidentalis, the apparent $M_{\mathrm{r}}$ of the kinase was about 72000 , the same order of magnitude as hexokinase from Sacch. cerevisiae (about 100000; Colowick, 1973). The hexose-ATP-kinase of the mutant 819-11 gave an identical peak.

Although in each experiment with the anion-exchange column, the peak for the Schw. occidentalis hexose-ATP-kinase was approximately symmetrical, the ratio of the rate of Dglucose phosphorylation to that of D-fructose phosphorylation $(G / F)$ showed a slight increase in 


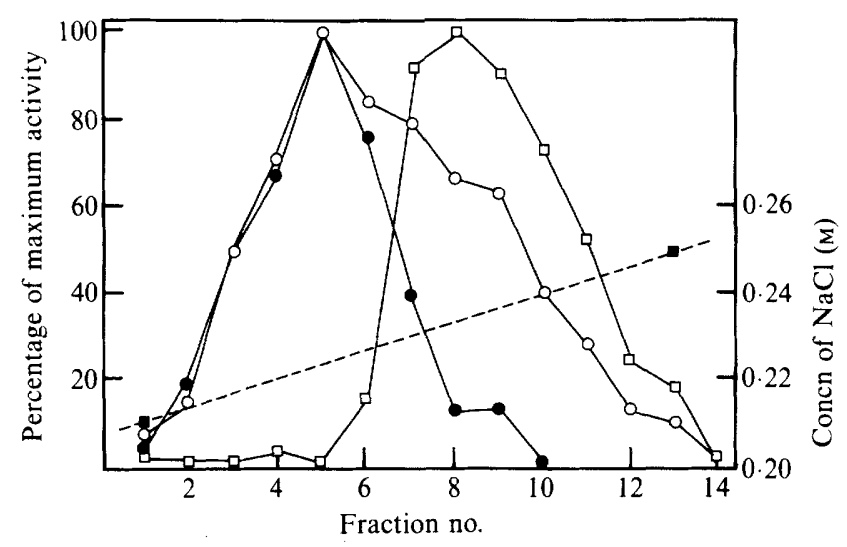

Fig. 2. Attempted separation of hexose-ATP-kinase activities of Schw. occidentalis. Crude extracts of CBS 819 (wild-type) and 819-11 (mutant) were combined, so that each component gave about the same total activity of D-glucose phosphorylation. The mixed extracts were chromatographed on an anionexchange column (Mono Q), eluted with a concentration gradient of $\mathrm{NaCl}$ in $20 \mathrm{~mm}$-piperazine buffer (pH 6.0). Hexose phosphorylation was measured as described in Methods. D- D-Fructose phosphorylation ('hexokinase' activity of enzyme 1); $\mathrm{O}-\mathrm{O}, \mathrm{D}$-glucose phosphorylation (combined 'hexokinase' activity and 'glucokinase' activities of enzymes 1 and 2); $\square-\square$, calculated 'glucokinase' activity of enzyme $2 ; \square---\mathbf{\square}$, concentration of $\mathrm{NaCl}$.

the last three fractions of the peak $(0.6 \mathrm{ml}$ in total); but, here, the activity was low and the experimental error correspondingly high. These observations were consistent with the presence in the wild-type of both hexokinase and glucokinase of the same molecular size and with only a slight difference in net charge. Assuming that there was loss of hexokinase (or hexokinase-like activity) in mutant 819-11, crude extracts of both wild-type and mutant were mixed, each with about the same activity towards D-glucose, and subjected to ion-exchange chromatography, in order to establish whether the two activities were separable.

Peaks were obtained for phosphorylation of $D$-fructose by enzyme from the wild-type and $D$ glucose by enzyme from both wild-type and mutant. Fig. 2 shows these peaks, the activity of each fraction being expressed as a percentage of that with maximum activity. Fractions $1-5$ had a constant $\mathrm{G} / \mathrm{F}$ ratio, indicating that a single enzyme (enzyme 1 ) is responsible for both phosphorylations. Fractions 6 to 14 gave a changing G/F ratio, providing evidence for the presence of a second (modified?) hexose-ATP-kinase (enzyme 2). From the results with the first five fractions, the G/F ratio was calculated for enzyme 1 and, from this, its rate of D-glucose phosphorylation calculated for the whole peak. By subtraction, the contribution of enzyme 2 , presumably a modified form of enzyme 1 , was also calculated and the relative position of the peak for its activity is also shown in Fig. 2.

\section{Electrophoresis}

The electrophoretogram bands for the hexose-ATP-kinase of crude or partly purified extracts of Schw. occidentalis wild-type and mutant 819-11 all had about the same mobility (Fig. 3). The distance moved towards the anode was the same for each preparation whether for D-glucose or $D$-fructose phosphorylation. Extracts of 819-11 gave no bands with $D$-fructose. By contrast, three separated groups of bands of D-glucose-phosphorylating activity were obtained with extracts of Sacch. cerevisiae, as described previously (e.g. Ramel et al., 1971; Muratsubaki \& Katsume, 1979). Multiple electrophoretic bands have been found for the hexokinase of other yeast species, such as Hanseniaspora uvarum (Kloeckera brevis) (Kopperschläger \& Hofmann, 1969).

\section{DNA hybridization}

The gene that codes for hexokinase PI $(H X K l)$ in Sacch. cerevisiae hybridizes strongly with that for hexokinase PII $(H X K 2)$ and its mutant allele, hex $l^{\text {r }}$ (Entian et al., 1984, 1985). 


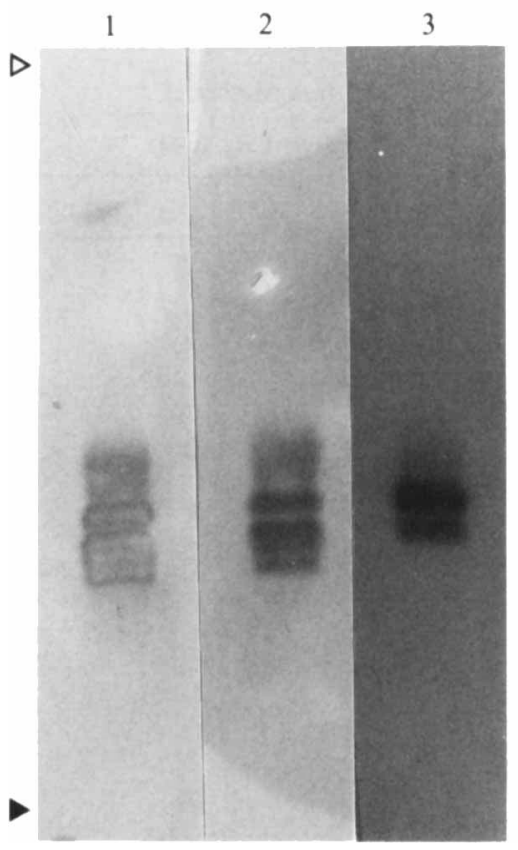

Fig. 3

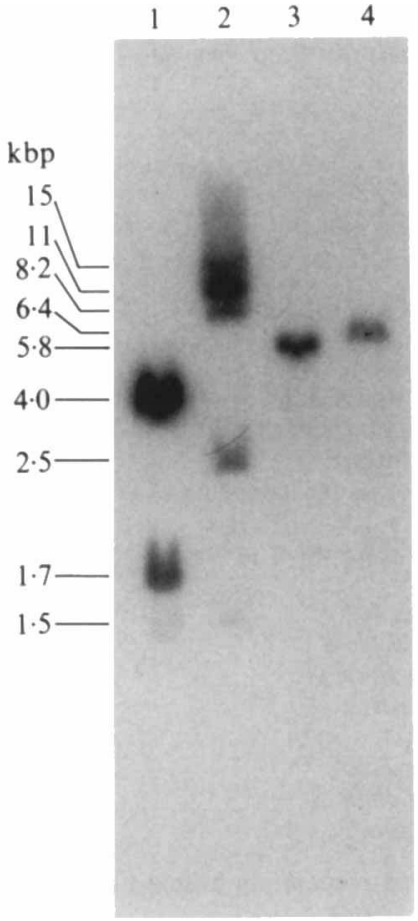

Fig. 4

Fig. 3. Cellulose acetate plate electrophoresis of partly purified hexose-ATP-kinase of Schw. occidentalis. Movement in the gel was from top $(D)$ to bottom $(\longrightarrow$, anode). CBS 819 wild-type, incubated with D-glucose; 2, CBS 819 wild-type, incubated with D-fructose; 3, mutant 819-11, incubated with D-glucose.

Fig. 4. Southern blot of genomic DNA of Schw. occidentalis CBS 819 (wild-type) and of Sacch. cerevisiae, hybridized with a mutant hexokinase PII gene, hex $I^{r}$. Lanes 1 and 2 , Sacch. cerevisiae cat 1.3314 A DNA digested with EcoRI (lane 1), and with HindIII (lane 2); lanes 3 and 4, Schw. occidentalis DNA digested with EcoRI (lane 3) and with HindIII (lane 4). Digested DNA was run on agarose gel electrophoresis. The hybridization probe was a [32P]dCTP-labelled hex ${ }^{\mathrm{r}}$ fragment.

With a ${ }^{32} \mathrm{P}$-labelled hex $I^{\mathrm{r}}$ fragment as probe against Sacch. cerevisiae catl.33-14 A, the EcoRI digest gave hybridization signals of 4.0 and $1.7 \mathrm{kbp}$ and the HindIII-digest gave about $15,11,8.2$ and $2.5 \mathrm{kbp}$, compared with a $\lambda$ standard (Fig. 4). The results with EcoRI-restricted DNA agreed closely with results of K.-D. Entian (1986, personal communication), which gave signals of 4.0 for hexokinase PII and $1.65 \mathrm{kbp}$ for hexokinase PI.

Using a ${ }^{32} \mathrm{P}$-labelled hex $I^{\mathrm{r}}$ fragment as a probe against $S c h w$. occidentalis, wild-type, the EcoRI digest gave a hybridization signal of $5.8 \mathrm{kbp}$ and the HindIII-digest gave $6.4 \mathrm{kbp}$, compared with a $\lambda$ standard (Fig. 4). Hence, there is a DNA sequence in Schw. occidentalis that shows homology with the hex $I^{r}$ gene of Sacch. cerevisiae. In addition, only one signal was observed, which is evidence for the presence of only a single hexokinase gene in Schw. occidentalis.

\section{Heat inactivation}

About $99 \%$ of D-fructose phosphorylating ability was lost when partly purified Schw. occidentalis hexose-ATP-kinase was heated to $45^{\circ} \mathrm{C}$ for $40 \mathrm{~min},>96 \%$ being lost within $8 \mathrm{~min}$. This was also found with crude extracts. There was a simultaneous loss of $73 \%$ of the ability to phosphorylate D-glucose, the residual $27 \%$ was stable at $45^{\circ} \mathrm{C}$ for $400 \mathrm{~min}$. During this time, another portion of the same enzyme preparation kept at $0{ }^{\circ} \mathrm{C}$ lost $<20 \%$ phosphorylating 
Table 1. Apparent Michaelis constants, $K_{\mathrm{m}}$, for phosphorylation of $\mathrm{D}-$ fructose by the partly purified hexose-ATP-kinase of Schw. occidentalis CBS 819 and comparison with other yeasts

The values were obtained at $\mathrm{pH} 7.6$ and $25^{\circ} \mathrm{C}$ (see Methods).

\begin{tabular}{|c|c|c|c|c|c|c|}
\hline \multirow[b]{3}{*}{ Expt. no.... } & \multicolumn{6}{|c|}{ Apparent $K_{\mathrm{m}}(\mathrm{mM})$} \\
\hline & \multicolumn{3}{|c|}{ D-Glucose } & \multicolumn{3}{|c|}{ D-Fructose } \\
\hline & 1 & 2 & 3 & 1 & 2 & 3 \\
\hline Wild-type ('hexokinase' + 'glucokinase') & 0.36 & $0 \cdot 35$ & $0 \cdot 32$ & $7 \cdot 2$ & 7.5 & 6.9 \\
\hline Mutant 11 ('glucokinase') & 0.091 & 0.077 & 0.065 & - & - & - \\
\hline Heated wild-type* & 0.082 & 0.076 & - & - & - & - \\
\hline Calculated value for 'hexokinase' site & 0.53 & 0.56 & - & - & - & - \\
\hline \multicolumn{7}{|l|}{ Values obtained for other species } \\
\hline \multicolumn{7}{|l|}{ Hexokinases } \\
\hline Candida maltosa $\dagger$ & & $0 \cdot 2$ & & & - & \\
\hline Candida tropicalis $\S$ & & $0 \cdot 34$ & & & $2 \cdot 2$ & \\
\hline Rhodotorula glutinis & & $0 \cdot 1-0 \cdot 2$ & & & $2 \cdot 0-3 \cdot 3$ & \\
\hline Sacch. cerevisiae & & $0 \cdot 1$ & & & $0 \cdot 7-1 \cdot 2$ & \\
\hline \multicolumn{7}{|l|}{ Glucokinases } \\
\hline Candida tropicalis $\S$ & & $0 \cdot 29$ & & & - & \\
\hline Rhodotorula glutinis & & $0 \cdot 10$ & & & - & \\
\hline Sacch. cerevisiaeq & & $0.02-0.4$ & & & - & \\
\hline $\begin{array}{l}\text { * Partly purified preparation heated to } 45^{\circ} \mathrm{C} \\
\text { † Röber et al. }(1984) \text {. } \\
\text { \$ Hirai et al. }(1977) \text {. } \\
\text { || Mazón et al. (1975); Mahlberg et al. (1985) } \\
\text { I Slein et al. (1950); Sols et al. (1958); Maitr }\end{array}$ & or $30 \mathrm{n}$ & . & & & & \\
\hline
\end{tabular}

activity towards D-fructose and there was no detectable loss of activity towards D-glucose. Hence, of the total D-glucose phosphorylating activity, $73 \%$ was attributable to the heat-labile 'hexokinase' site and $27 \%$ to the heat-stable 'glucokinase' site.

When crude extract of wild-type Schw. occidentalis had been incubated at $45^{\circ} \mathrm{C}$ for $30 \mathrm{~min}$, the hexose-ATP-kinase gave a single peak when run through the gel-filtration column (Superose 12), coincident with the peaks for the enzymes from extracts of unheated wild-type and mutant.

Kinetic characteristics of the hexose-ATP-kinase

Table 1 shows apparent Michaelis constants, $K_{\mathrm{m}}$, for D-glucose and for D-fructose, of the partly purified hexose-ATP-kinase of Schw. occidentalis, from the wild-type CBS 819, Dog ${ }^{\mathrm{R}}$ mutant 819-11 and heat-treated wild-type; constants reported by other workers for different yeast species are also shown. Constants obtained with crude extracts were closely comparable to those with fractionated preparations.

The apparent $K_{\mathrm{m}}$ for D-glucose differed markedly between wild-type (mean $0.34 \mathrm{~mm}$ ) and mutant $(0.078 \mathrm{mM})$. This difference may be compared to that between the hexokinase and glucokinase of Sacch. cerevisiae (Table 1; Slein et al., 1950; Sols et al., 1958; Maitra, 1970). Extracts from wild-type Schw. occidentalis, maintained for $30 \mathrm{~min}$ at $45^{\circ} \mathrm{C}$, behaved indistinguishably from those of mutant 819-11. These results were consistent with the loss by the mutant of either (i) a hexokinase, leaving a glucokinase, or (ii) a catalytic site with hexokinaselike specificity, leaving a glucokinase-like site. Assuming one of these alternatives to be true, by subtracting individual measurements, a value was calculated for the apparent $K_{\mathrm{m}}$ for the $S c h w$. occidentalis 'hexokinase' site (or hexokinase) as $0.55 \mathrm{mM}-\mathrm{D}$-glucose.

The $K_{\mathrm{m}}$ of the hexose-ATP-kinase for D-fructose ( $7.2 \mathrm{mM}$ ) was much higher than that for Dglucose, as has been found for the hexokinases of other yeasts (Table 1). In aqueous solution at $25^{\circ} \mathrm{C}$, about $25 \%$ of D-fructose is in the furanose configuration (Horton \& Wałaszek, 1982; Angyal, 1984). Assuming it to be the furanose and not the pyranose form of D-fructose that is the 
substrate for these kinases (Slein et al., 1950; Kalckar, 1985), the $K_{\mathrm{m}}$ for D-fructose would be about $1.8 \mathrm{~mm}$.

The phosphorylation of D-glucose or D-fructose was measured with various nucleoside $5^{\prime}$ triphosphates other than ATP, namely CTP, ITP, GTP or UTP. Whilst CTP, GTP and UTP gave rates that were $<1 \%$ that with ATP, ITP gave a significant rate of phosphorylation, about 6-7\% of that with ATP, both with D-glucose or D-fructose for wild-type Schw. occidentalis and with D-glucose for mutant 819-11. That the ratios were the same for both D-glucose and Dfructose is consistent with a single enzyme being responsible for both phosphorylations. Marked activity with only ITP among the ATP analogues is consistent with findings for hexokinase in Sacch. cerevisiae (Purich et al., 1973).

\section{Conclusions}

Two clear alternative interpretations of the results of these investigations are as follows. First, in Schw. occidentalis wild-type (CBS 819), a hexokinase and a glucokinase were separate enzymes, and the mutant 819-11 had lost the hexokinase. Alternatively, a single hexose-ATPkinase of the wild-type had two catalytic sites, one hexokinase-like and the other glucokinaselike, the mutant having lost the hexokinase-like site.

Neither chromatography nor electrophoresis, nor yet DNA hybridization, gave any evidence of more than one hexose-ATP-kinase in either wild-type or mutant strains. However, there was slight separation of these two enzymes by anion-exchange, but not by gel-filtration chromatography. This separation could indicate that the modification to the enzyme in the mutant was also associated with a slight difference in charge or that adding the mutant enzyme to that of the wild-type made it possible to observe the second peak which, for the wild-type alone, was obscured by the large hexokinase peak. However, heating the wild-type enzyme appeared to alter its activity, specificity and kinetics, so that it was then closely comparable to the mutant enzyme. Hence, the authors tend to favour the view that there were two catalytic sites on a single polypeptide. This does not seem to have been reported previously for a hexose-ATPkinase. However, such a 'double-headed' enzyme has been described for Escherichia coli, in which aspartate kinase (EC 2.7.2.4) and homoserine dehydrogenase (EC 1.1.1.3) have been shown to be located on one polypeptide, so that a single protein performs both functions (reviewed by Cohen \& Dautry-Varsat, 1980).

We would like to thank, most warmly, the colleagues who have helped us in this work, particuarly J. A. Bangham, K. F. Chater, A. P. Dawson, K.-D. Entian, K.-U. Fröhlich, R. James, R. Nichols, A. P. Sims and Sim F. Webb. The work was financed by the Ministry of Agriculture, Fisheries and Food.

\section{REFERENCES}

ANGyal, S. J. (1984). The composition of reducing sugars in solution. Advances in Carbohydrate Chemistry and Biochemistry 42, 15-68.

Bangham, J. A. (1985). Statstream. Cambridge: Elsevier Biosoft.

BARNARD, E. A. (1975). Hexokinases from yeast. Methods in Enzymology 42, 6-20.

BARNETT, J. A. (1976). The utilization of sugars by yeasts. Advances in Carbohydrate Chemistry and Biochemistry 32, 125-234.

BARNETT, J. A. (1981). The utilization of disaccharides and some other sugars by yeasts. Advances in Carbohydrate Chemistry and Biochemistry 39, 347404.

BARnetT, J. A. \& Kornberg, H. L. (1960). The utilization by yeasts of acids of the tricarboxylic acid cycle. Journal of General Microbiology 23, 65-82.

CIRIACY, M. (1976). Cis-dominant regulatory mutations affecting the formation of glucose-repressible alcohol dehydrogenase (ADHII) in Saccharomyces cerevisiae. Molecular and General Genetics 145, 327-333.
Cohen, G. N. \& Dautry-Varsat, A. (1980). The aspartokinases-homoserine dehydrogenases of Escherichia coli. In Multifunctional Proteins, pp. 49-121. Edited by $\mathrm{H}$. Bisswanger \& E. Schmincke-Ott. New York: Wiley.

Colowick, S. P. (1973). The hexokinases. In The Enzymes, 3rd edn, vol. 9, pp. 1-48. Edited by P. D. Boyer. New York: Academic Press.

Colquhoun, D. (1971). Lectures on Biostatistics. Oxford: Clarendon press.

Dretzen, G., Bellard, M., Sassone-Cersi, P. \& Chambon, P. (1981). A reliable method for the recovery of DNA fragments from agarose and acrylamide gels. Analytical Biochemistry 112, 195198.

ENTIAN, K.-D. (1980). Genetic and biochemical evidence of hexokinase PII as a key enzyme involved in carbon catabolite repression in yeast. Molecular and General Genetics 178, 633-637.

ENTIAN, K.-D. \& MECKe, D. (1982). Genetic evidence for a role of hexokinase isoenzyme PII in carbon 
catabolite repression in Saccharomyces cerevisiae. Journal of Biological Chemistry 257, 870-874.

ENTIAN, K.-D., KopetZKI, E., FröHLICH, K.-U. \& MECKE, D. (1984). Cloning of hexokinase isoenzyme PI from Saccharomyces cerevisiae: PI transformants confirm the unique role of hexokinase isoenzyme PII for glucose repression in yeasts. Molecular and General Genetics 198, 50-54.

Entian, K.-D., Hilberg, F., Opitz, H. \& Mecke, D. (1985). Cloning of hexokinase structural genes from Saccharomyces cerevisiae mutants with regulatory mutations responsible for glucose repression. Molecular and Cellular Biology 5, 3035-3040.

FAHRNEY, D. E. \& Gold, A. M. (1963). Sulfonyl fluorides as inhibitors of esterases. I. Rates of reaction with acetylcholinesterase, $\alpha$-chymotrypsin, and trypsin. Journal of the American Chemical Society 85, 997-1000.

Fernández, R., Herrero, P. \& Moreno, F. (1985). Inhibition and inactivation of glucose-phosphorylating enzymes from Saccharomyces cerevisiae by Dxylose. Journal of General Microbiology 131, 27052709.

Fromm, H. J. \& ZeWE, V. (1962). Kinetic studies of yeast hexokinase. Journal of Biological Chemistry 237, 3027-3032.

GANCEDO, C. \& SchwerzmanN, N. (1976). Inactivation by glucose of phosphoenolpyruvate carboxykinase from Saccharomyces cerevisiae. Archives of Microbiology 109, 221-225.

Gancedo, C., Salas, M. L., Giner, A. \& Sols, A. (1965). Reciprocal effects of carbon sources on the level of an AMP-sensitive fructose-1,6-diphosphatase and phosphofructokinase in yeast. Biochemical and Biophysical Research Communications 20, 15-20.

Gancedo, J.-M., Clifton, D. \& Fraenkel, D. G. (1977). Yeast hexokinase mutants. Journal of Biological Chemistry 252, 4443-4444.

HaArasilta, S. \& OURA, E. (1975). On the activity and regulation of anaplerotic and gluconeogenetic enzymes during the growth process of baker's yeast. European Journal of Biochemistry 52, 1-7.

HiRai, M., Ohtani, E., TANaKa, A. \& Fukui, S. (1977). Glucose-phosphorylating enzymes of Candida yeasts and their regulation in vivo. Biochimica et biophysica acta 480, 357-366.

HoRTON, D. \& WAlAszeK, Z. (1982). Tautomeric equilibria of some sugars by partially relaxed ${ }^{13} \mathrm{C}$ pulse Fourier-transform, nuclear magnetic resonance spectroscopy. Carbohydrate Research 105, 145-153.

KaLCKar, H. M. (1985). The discovery of hexokinase. Trends in Biochemical Sciences 10, 291-293.

Kelly, R. B., Cozzarelli, N. R., DeUtSCher, M. P., LeHMANN, J. R. \& KoRnberG, A. (1970). Enzymatic synthesis of deoxyribonucleic acid by polymerase at a single strand break. Journal of Biological Chemistry 245, 39-45.

KOPETZKI, E. \& ENTIAN, K.-D. (1985). Glucose repression and hexokinase isoenzymes in yeast. Isolation and characterization of a modified hexokinase PII isoenzyme. European Journal of Biochemistry 146, 657-662.

KOPPERSCHLÄGER, G. \& HoFMANN, E. (1969). Über multiple Formen der Hexokinase in Hefe. European Journal of Biochemistry 9, 419-423.
Lobo, Z. \& MaITRA, P. K. (1977a). Physiological role of glucose-phosphorylating enzymes in Saccharomyces cerevisiae. Archives of Biochemistry and Biophysics 182, 639-645.

LOBO, Z. \& MAITRA, P. K. (1977b). Resistance to 2deoxyglucose in yeast: a direct selection of mutants lacking glucose phosphorylating enzymes. Molecular and General Genetics 157, 297-300.

LOBO, Z. \& MaITRA, P. K. (1977c). Genetics of yeast hexokinase. Genetics 86, 727-744.

MAHLberG, D., HöFER, M. \& TÄUbeR, A. (1985). Sugar transport and hexose-ATP-kinase activity in a 2-deoxy-D-glucose tolerant mutant of the yeast Rhodotorula glutinis. Journal of General Microbiology 131, 479-485.

MahleR, H. R., Jaynes, P. K., McDonough, J. P. \& Hanson, D. K. (1981). Catabolite repression in yeast: mediation by cAMP. Current Topics in Cellular Regulation 18, 455-474.

MAITRA, P. K. (1970). A glucokinase from Saccharomyces cerevisiae. Journal of Biological Chemistry 245, 2423-2431.

MAITRA, P. K. (1975). Glucokinase from yeast. Methods in Enzymology 42, 25-30.

MAITRA, P. K. \& Lово, Z. (1983). Genetics of yeast glucokinase. Genetics 105, 501-515.

Maniatis, T., Fritsch, E. F. \& SambrooK, J. (1982). Molecular Cloning. Cold Spring Harbor, NY: Cold Spring Harbor Laboratory.

Mazón, M. J., Gancedo, J.-M. \& Gancedo, C. (1975). Hexose kinases from Rhodotorula glutinis. Identification and properties of a hexokinase and a glucokinase. Archives of Biochemistry and Biophysics 167, 452-457.

McCann, A. K. \& Barnett, J. A. (1984). Starch utilization by yeasts: mutants resistant to carbon catabolite repression. Current Genetics 8, 525-530.

MCCANN, A. K. \& BARNETT, J. A. (1986). The utilization of starch by yeasts. Yeast 2, 109-115.

Mitchell, P. (1949). A new technique for stirred aerated culture. Nature, London 164, 846-847.

Muratsubaki, H. \& Katsume, T. (1979). Distribution of hexokinase isoenzymes depending on a carbon source in Saccharomyces cerevisiae. Biochemical and Biophysical Research Communications 86, 1030 1036.

Polakis, E. S. \& Bartley, W. (1965). Changes in enzyme activities in Saccharomyces cerevisiae during aerobic growth on different carbon sources. Biochemical Journal 97, 284-297.

PURICH, D. L., Fromm, H. J. \& RUdOLPH, F. B. (1973). The hexokinases: kinetic, physical and regulatory properties. Advances in Enzymology and Related Areas of Molecular Biology 39, 249-326.

RAmel, A. H., Rustum, Y. M., Jones, J. G. \& BARNARD, E. A. (1971). Yeast hexokinase. IV. Multiple forms of hexokinase in the yeast cell. Biochemistry 10, 3499-3508.

Röber, B., Stolle, J. \& Reuter, G. (1984). Eigenschaften der Hexokinase aus der SCP Hefe Candida maltosa $\mathrm{H}$. Zeitschrift für allgemeine Mikrobiologie 24, 619-627.

SChulze, I. T., Gazith, J. \& Gooding, R. H. (1966). Hexokinase II. Bakers' yeast (modifications in procedure). Methods in Enzymology 9, 376-381.

SEARLE, J. B. (1985). Isoenzyme variation in the 
common shrew (Sorex araneus) in Britain, in relation to karyotype. Heredity 55, 175-180.

Slein, M. W., CORI, G. T. \& CORI, C. F. (1950). A comparative study of hexokinase from yeast and animal tissues. Journal of Biological Chemistry 186, 763-780.

Sols, A., De la Fuente, G., Villar-Palasi, C. \& AsENSIO, C. (1958). Substrate specificity and some other properties of baker's yeast hexokinase. Biochimica et biophysica acta 30, 92-101.

SOUTHERN, E. M. (1975). Detection of specific se- quences among DNA fragments separated by gel electrophoresis. Journal of Molecular Biology 98, 503-517.

WitT, I., Kronau, R. \& Holzer, H. (1966). Repression von Alkoholdehydrogenase, Malatdehydrogenase, Isocitratlyase und Malatsynthase in Hefe durch Glucose. Biochimica et biophysica acta 118, 522-537. ZimmermanN, F. K. \& SCHEEL, I. (1977). Mutants of Saccharomyces cerevisiae resistant to carbon catabolite repression. Molecular and General Genetics 154, 75-82. 